\title{
Effects of different media on the growth and yield of Swiss chard (Beta vulgaris var. cicla) grown in hydroponics
}

\begin{abstract}
Decline in the availability of suitable land and good fertile soil for vegetable production due to climate change, urbanisation and increasing population has resulted in studies to find alternative media that can be used to grow high value crops such as Swiss chard. The experiment was conducted at the Horticulture Department Greenhouses of the University of Eswatini, Luyengo Campus to determine the growth and yield of Swiss chard using different growing media. The treatments were laid out in a Randomised Complete Block Design (RCBD) and replicated four times. The media treatments consisted of sand, sawdust and mixture of sand and vermiculite $(1: 1)$. The results showed that Swiss chard grown in sawdust performed better than those in the other growing media and gave significantly $(\mathrm{P}<0.05)$ higher fresh yield $(227.7 \mathrm{~g} /$ plant $)$, root length $(25 \mathrm{~cm} / \mathrm{plant})$ and the highest chlorophyll content $\left(48.9 \mu \mathrm{mol} \mathrm{m} \mathrm{m}^{2}\right)$. Plants grown using sand had the lowest fresh yield (58.3 g/plant), root length $(11.9 \mathrm{~cm} /$ plant $)$ and the chlorophyll content $\left(17.49 \mu \mathrm{mol} \mathrm{m} \mathrm{m}^{2}\right)$. The results showed that Swiss chard production in hydroponics using sawdust resulted in higher yields and therefore should be recommended to farmers for use. Not only is it the best in production of Swiss chard but it is also readily available at low cost and re-usable provided it is treated.
\end{abstract}

Keywords: Growing media, hydroponics, Swiss chard, food and nutritional security, sustainable development goals (SDGs), climate-smart agriculture
Volume 3 Issue 3 - 2019

\section{Phumelele A Hlophe, Kwanele A Nxumalo, Tajudeen O. Oseni, Michael T Masarirambi, Paul KWahome,Victor D Shongwe}

Department of Horticulture, Faculty of Agriculture, University of Eswatini, Southern Africa

\author{
Correspondence: Kwanele A Nxumalo, Department of \\ Horticulture, Faculty of Agriculture, University of Eswatini, PO \\ Box Luyengo M205, Eswatini, Southern Africa, \\ Email aknxumalo@uniswa.sz
}

Received: April 14, 2019 | Published: June 04, 2019

\section{Introduction}

Swiss chard (Beta vulgaris var. cicla) belongs to the Amaranthaceae and is an annual cool season, green leafy vegetable which is eaten raw. ${ }^{1}$ Swiss chard is thought to have originated in ancient Persia (Iran) and it is now cultivated throughout the world. ${ }^{2}$ Depending on the cultivar, the leaves are larger, sweet tender and smoother than semi-savoy Swiss chard. Swiss chard has high water content and is harvested 40 days after transplanting. ${ }^{3}$

Swiss chard is often used in salads because of its appealing flavour and delicate texture. The stalks should also be eaten because they are still tender. ${ }^{2}$ Swiss chard is a long day plant that is prone to bolting during summer. ${ }^{1}$ There is an increasing awareness in the value of leafy vegetables contributing to a balanced diet, particularly in area where animal protein is deficient. Leafy vegetables contribute significantly to the amount of carotene, vitamin $\mathrm{C}$, protein, and minerals particularly calcium. In addition to the health benefits mentioned above, Swiss chard has an advantage of a short culture time and shelf-life. ${ }^{4}$

One method of reducing the water demand for vegetable irrigation besides using recent irrigation technology methods is through hydroponics. Hydroponics is a technology of growing plants in nutrient solution (water containing fertiliser) with or without the use of artificial media in the absence of soil. ${ }^{5}$ The nutrients needed by plants are supplied by the nutrient solution. Pesticides and other chemicals used in conventional agriculture have an adverse environmental impact with the runoff from these chemical contaminating groundwater supplies. Commercial hydroponics systems eliminate these toxic chemicals and contribute substantially to keeping groundwater free from contamination. The advantage of growing vegetables in hydroponics includes the extension of the growing season, improved and consistent vegetable quality and elimination of the use of pesticides and herbicides. ${ }^{6}$

Worldwide, a high percentage of the hydroponic industry uses inorganic growing media such as rockwool, sand, perlite, vermiculite, pumice, clays, expanded polystyrene, urea formaldehydes. Only about $12 \%$ use organic growing media such as peat, bark, wood residues (leaf mould, sawdust, and barks), coir, bagasse, rice hulls and others. ${ }^{7}$ However, there is no growing medium that can be labelled as "best" since each particular medium has both advantages and disadvantages. Several factors determine the type of growing medium appropriate for specific growing conditions. Although crop performance (yield and quality) is usually the primary factor in developing a growing medium, other traits such as cost, re-use or recycling potentials are critical for a sustainable production system. Various materials are used for substrate preparation such as peat, pine bark, sawdust, cocofiberand cacao shell. ${ }^{7}$ The physical and chemical characteristics of the medium, together with the growing techniques (e.g., fertigation) employed, will determine the yield and quality of the vegetables that will be produced. ${ }^{7}$

Controlled environmental agriculture (CEA), of which the main component is hydroponics, is the only solution to meet the demands of consumers, especially in areas where environmental conditions are not conducive to vegetable production. Hydroponics vegetable production may benefit countries with acute shortage of land and irrigation water. However, this technology has not yet been widely adopted in the Kingdom of Eswatini despite its popularity worldwide. The purpose of this study was to evaluate the effects of the different hydroponics growing media on growth and yield Swiss chard. The 
identification of a suitable growing media for Swiss chard production using hydroponics will increase its availability and income for farmers thus reducing poverty and ensuring food security at household level.

\section{Materials and methods}

\section{Experimental site}

The experiment was carried out in the greenhouse of the Horticulture Department, Faculty of Agriculture, Luyengo Campus of the University of Eswatini during the 2017/2018 cropping season between October and December. The site is located at Luyengo in the Manzini Region in the Middleveld agro ecological zone. Luyengo is $26^{\circ} 34 \mathrm{~S}$ and $31^{\circ} 12 \mathrm{E}$ at an altitude of $730 \mathrm{~m}$. The average summer maximum temperatures are $27^{\circ} \mathrm{C}$ and $15^{\circ} \mathrm{C}$ in winter. The mean precipitation is $980 \mathrm{~mm}$ with most of the rain falling between October and March. ${ }^{8}$

\section{Experimental layout and design}

The experiment was laid out in a Randomised Complete Block Design (RCBD) and each treatment was replicated four times. The treatments were: sawdust, sand and a mixture of vermiculite and sand $(1: 1)$.

\section{Plant material}

Five-weeks old Swiss chard seedlings were bought at National Agricultural Marketing Board (NAMBoard), Matsapha, Eswatini. At transplanting, compost around the roots of the seedlings was gently removed using running water. The seedlings were then transplanted to the different treatments as indicated above. Elevated tray hydroponics system was used to grow the transplants and they were fertigated using the flood and drain basin system. After transplanting the transplants were supplied with nutrient solution.

\section{Media analysis}

The samples were taken to the Department of Crop Production in the Chemistry Laboratory of the University of Eswatini, Luyengo Campus for analysis of nitrogen, phosphorus, potassium, and $\mathrm{pH} .{ }^{9}$

\section{Preparation of nutrient solution}

The nutrient solutions were prepared using calcium nitrate fertiliser, Omnia Nutriology [Republic of South Africa (RSA)] (155 $\mathrm{g} / \mathrm{kg} \mathrm{N}$ and $195 \mathrm{~g} / \mathrm{kg} \mathrm{Ca}$ ) and Hydrogrow, a water soluble hydroponics fertiliser mix [Ocean, Muldersdrift, RSA] (total N $64 \mathrm{~g} / \mathrm{kg}$ [NH -N $10 \mathrm{~g} / \mathrm{kg}$, NO -N 54g/kg], P $4543 \mathrm{~g} / \mathrm{kg}, \mathrm{K} 239 \mathrm{~g} / \mathrm{kg}, \mathrm{Mg} 31 \mathrm{~g} / \mathrm{kg}$, S 59 $\mathrm{g} / \mathrm{kg}, \mathrm{Cl} 15 \mathrm{~g} / \mathrm{kg}, \mathrm{Fe} 1,680 \mathrm{mg} / \mathrm{kg}$, Mn $400 \mathrm{mg} / \mathrm{kg}$, B $500 \mathrm{mg} / \mathrm{kg}, \mathrm{Cu}$ $30 \mathrm{mg} / \mathrm{kg}$ and Mo $50 \mathrm{mg} / \mathrm{kg}$ ). The concentration of the fertiliser was $1.0 \mathrm{mS} / \mathrm{cm}$ for the first four weeks and then increased to $2.0 \mathrm{mS} / \mathrm{cm}$ thereafter until final harvest. The nutrient solution was maintained at the $\mathrm{pH}$ range of 6.5-7.0. Potassium hydroxide was used to raise the $\mathrm{pH}$ of the nutrient solution if lower than the optimal $\mathrm{pH}$ range, while phosphoric acid was used for reducing it if it was higher.

\section{Data collection}

A random sample of five plants per bench (replicate) was used for data collection. Data were collected four weeks after transplanting (WAT) and subsequently every week for a period of four weeks. The data collected included: number of branches per plant, leaf length and width, number of leaves, root: shoot ratio, fresh and dry mass, and chlorophyll content. The leaf area (LA) was calculated using the formulae: $\mathrm{LA}=422.973+22.752 \mathrm{~L}+8.31 \mathrm{~W} .^{10}$

\section{Data analysis}

The data collected were subjected to analysis of variance (ANOVA) using MSTAT-C statistical package. ${ }^{11}$ Where significant differences were detected, mean separation was done using the Duncan's New Multiple Range Test (DNMRT) at 5\% probability level. ${ }^{12}$

\section{Results}

\section{Media analysis}

Media analysis results indicated (Table 1) that sawdust had the lowest $\mathrm{pH}$ value (4.5), sand was neutral (7.0) and mixture of sand and vermiculite (1:1) was 7.0. The highest nitrogen content was obtained from sawdust $(1.0 \mathrm{mg} / \mathrm{kg})$ followed by mixture $(0.5 \mathrm{mg} / \mathrm{kg})$ and sand had the lowest value of $0.01 \mathrm{mg} / \mathrm{kg}$. Sawdust contained the highest level of phosphorus $(12.8 \mathrm{mg} / \mathrm{kg})$ whilst sand had the lowest $(0.002$ $\mathrm{mg} / \mathrm{kg})$. Sawdust had the highest potassium $(0.89 \mathrm{mg} / \mathrm{kg})$ whilst sand had only $0.03 \mathrm{mg} / \mathrm{kg}$.

Table I Physical and chemical composition of media used in the experiment

\begin{tabular}{|c|c|c|c|c|}
\hline Media & $\begin{array}{l}\text { Nitrogen } \\
\text { (mg/kg) }\end{array}$ & $\begin{array}{l}\text { Phosphorus } \\
\text { (mg/kg) }\end{array}$ & $\begin{array}{l}\text { Potassium } \\
\text { (mg/kg) }\end{array}$ & $\mathrm{pH}$ \\
\hline Sand & 0.01 & 0.002 & 0.03 & 7 \\
\hline Sawdust & I & 12.8 & 0.89 & 4.5 \\
\hline $\begin{array}{l}\text { Mixture of sand } \\
\text { and vermiculite } \\
(I: I)\end{array}$ & 0.5 & 5.6 & 0.53 & 7 \\
\hline
\end{tabular}

\section{Number of leaves}

There were no significant $(\mathrm{P}>0.05)$ differences in the number of leaves of Swiss chard grown in different media. The highest number of leaves (8.7) was obtained in plants grown using the mixture of sand and vermiculite (1:1) (Figure 1). There was a rapid decrease in the number of leaves between 4 and 6 WAT. The lowest number of leaves (6.35), was obtained from plants grown using sand (Figure 1). The second best results were obtained from plants grown using sawdust.

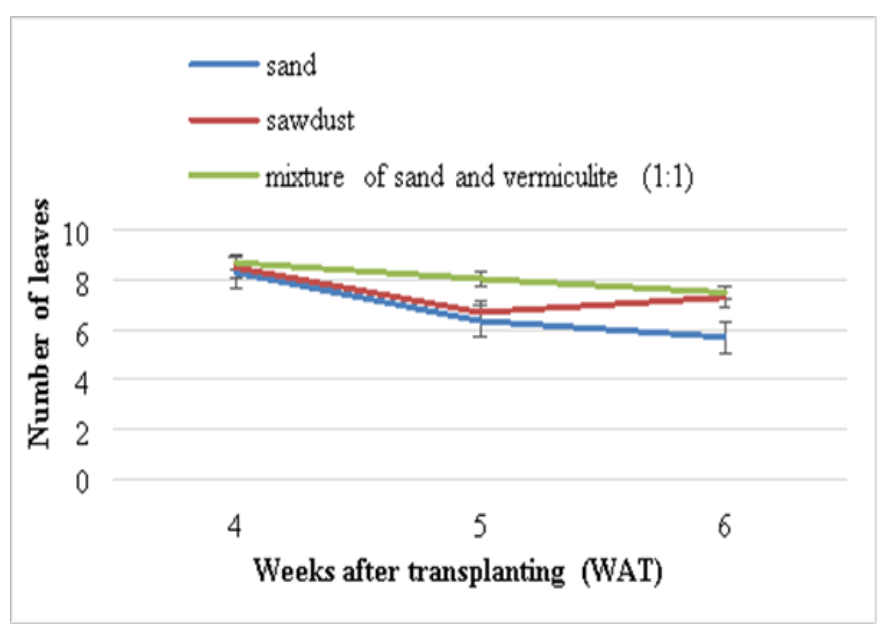

Figure I Effects of different media on number of leaves of Swiss chard.Vertical bars are standard error (SE) below and above the mean.

\section{Chlorophyll content}

There were significant $(\mathrm{P}<0.05)$ differences in chlorophyll content of Swiss chard grown in sand, sawdust and mixture of vermiculite and sand. At 5 WAT, the highest chlorophyll content $\left(48.9 \mu \mathrm{molm}^{2}\right)$ 
was obtained from plants chard grown in sawdust (Figure 2). The lowest chlorophyll content $\left(17.4 \mu \mathrm{mol} \mathrm{m}{ }^{2}\right)$ was obtained in the plants grown using sand and the second best results were obtained from those grown in mixture of sand and vermiculite (1:1). Generally the chlorophyll content decreased in all the treatments after 5 WAT.

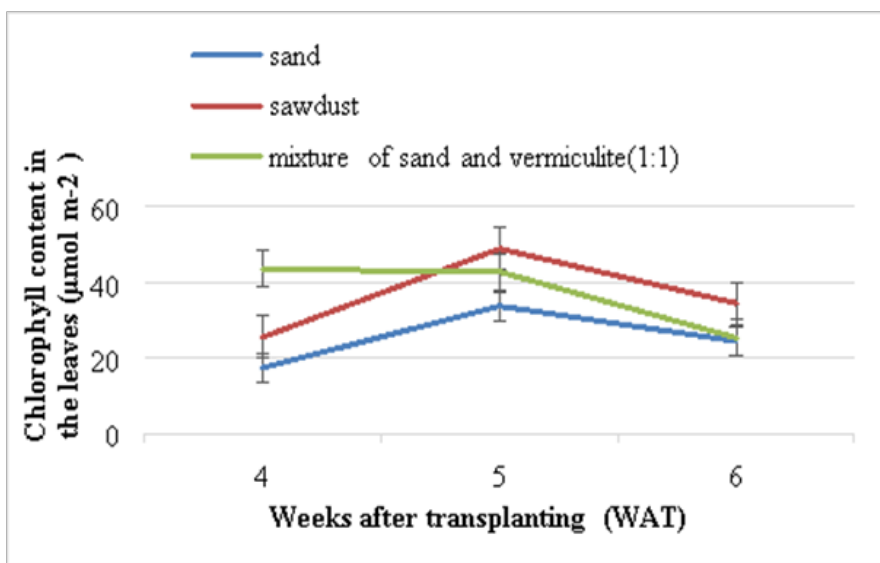

Figure 2 Effects of different media on the chlorophyll content $\left(\mu \mathrm{molm}{ }^{2}\right)$ the leaves of Swiss chard.Vertical bars are standard error (SE) below and above the mean.

\section{Length of roots}

There were significant $(\mathrm{P}<0.01)$ differences in root length of Swiss chard grown in different media (Figure 3 ). The highest root length $(25$ $\mathrm{cm}$ ) was obtained from plants grown in the mixture. The lowest root length $(11.9 \mathrm{~cm})$ was obtained from plants grown using sand and the second best results were obtained from plants grown in mixture of sand and vermiculite (1:1) (Figure 3). Plants grown in sawdust had more than double the root length obtained from those grown using sand.

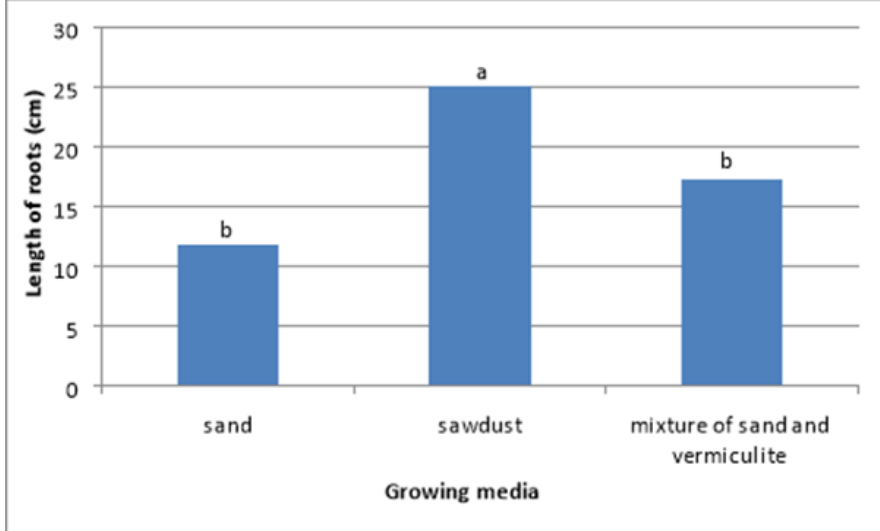

Figure 3 Effect of different media on the length of Swiss chard roots. Bars followed by same letter not significantly different. Mean separation by DNMRT at $\mathrm{P}=0.05$.

\section{Fresh mass of leaves}

There were significant $(\mathrm{P}<0.05)$ differences in fresh mass of leaves of Swiss chard grown in different media. At 6 WAT, the highest fresh mass of leaves $(227.7 \mathrm{~g})$ was obtained in Swiss chards grown in the sawdust and the lowest mass (58.3 g) in Swiss chard grown using sand (Figure 4). The second best results were obtained from Swiss chard grown in mixture of sand and vermiculite (1:1).

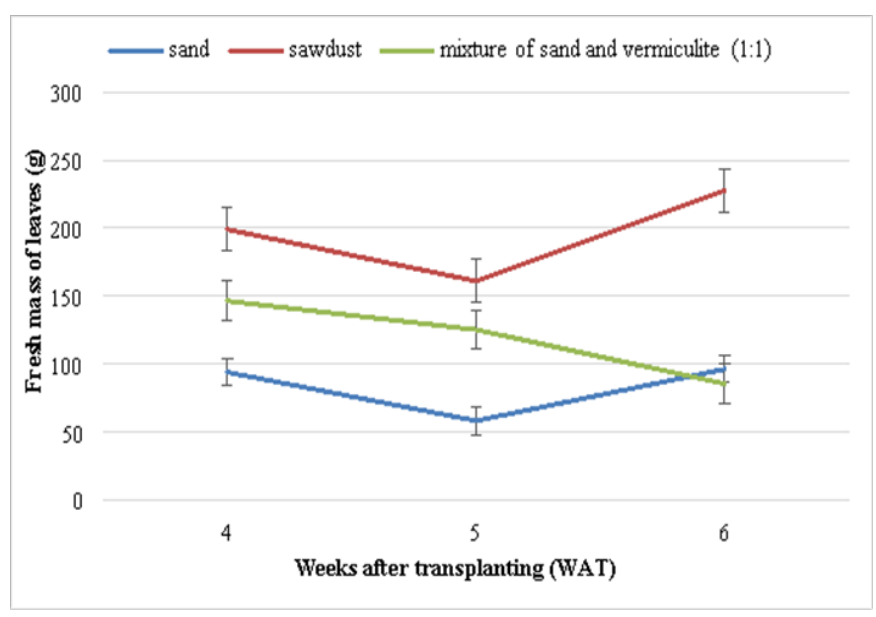

Figure 4 Effect of different media on fresh mass of leaves of Swiss chard. Vertical bars are standard error (SE) below and above the mean.

\section{Fresh and dry mass of roots}

There were significant $(\mathrm{P}<0.05)$ differences in root fresh mass of Swiss chard grown in sand, sawdust and mixture (Figure 5). The highest fresh root mass $(17.7 \mathrm{~g})$ was obtained from Swiss chard grown in the sawdust and the lowest mass was $(2.3 \mathrm{~g})$ from Swiss chard grown using sand. The second best results were obtained from plants grown in mixture. There was no significant $(\mathrm{P}>0.05)$ difference in root dry mass of Swiss chard grown in different media (Figure 5). The highest dry root mass $(3.9 \mathrm{~g})$ was obtained from plants grown in the sawdust and the lowest $(3.3 \mathrm{~g})$ from those grown using sand. The second best results were obtained from plants grown in mixture of sand and vermiculite (1:1) (Figure 5).

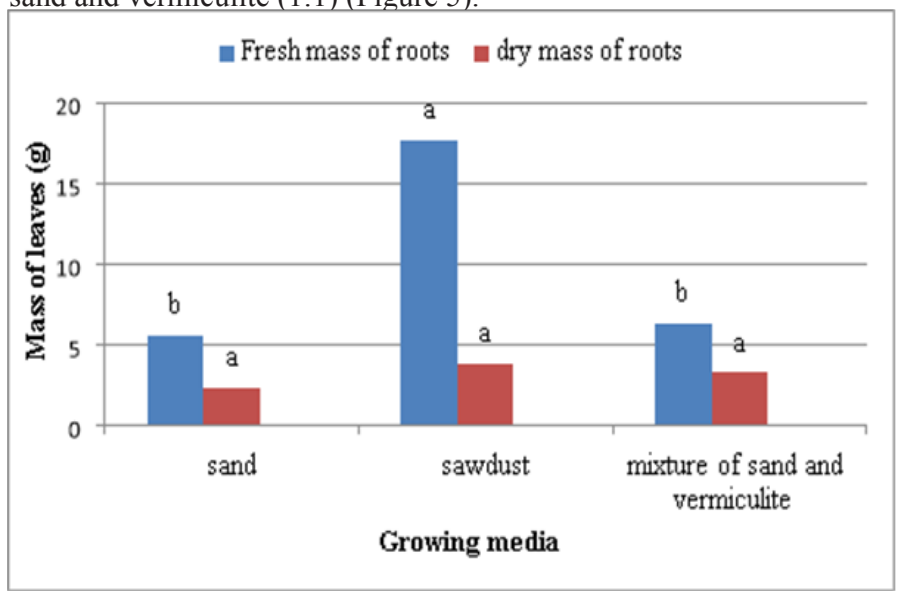

Figure 5 Effect of different media on the fresh and dry mass of roots of Swiss chard. Bars for each parameter followed by same letter not significantly different. Mean separation by DNMRT at $\mathrm{P}=0.05$.

\section{Dry mass of leaves}

There were significant $(\mathrm{P}<0.05)$ differences in the dry mass of leaves among the different growing media. The highest dry mass of leaves $(36.5 \mathrm{~g})$ was obtained in Swiss chard grown in the sawdust and the lowest mass (30.7 g) in Swiss chard grown using sand (Figure 6). The second best results were obtained from Swiss chard grown in mixture of sand and vermiculite (1:1). 


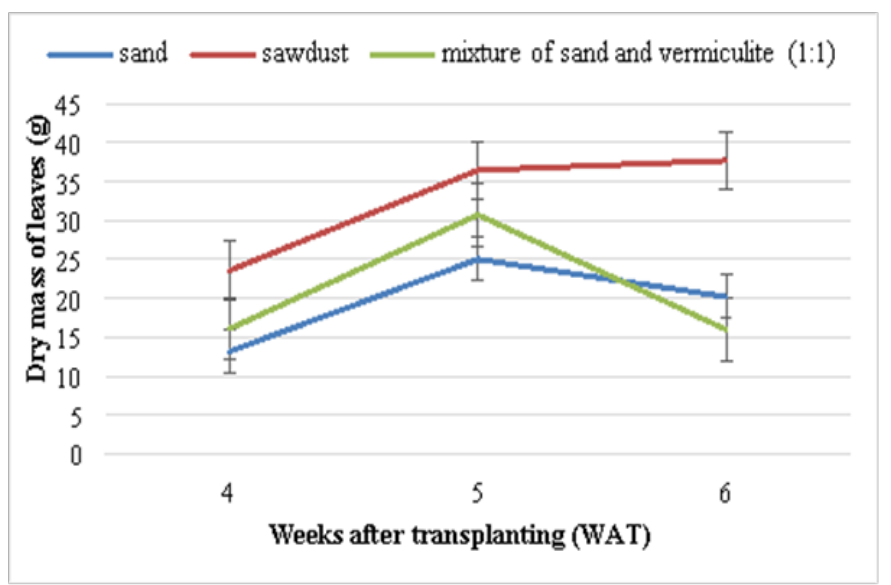

Figure 6 Effect of different media on the dry mass of leaves of Swiss chard. Vertical bars are standard error (SE) below and above the mean.

\section{Leaf area}

There were significant $(\mathrm{P}<0.05)$ differences in leaf area among the Swiss chard grown in the different growing media. At 6 WAT, Swiss chard grown in mixture had the highest leaf area $\left(271 \mathrm{~cm}^{2}\right)$ while the lowest leaf area $\left(110 \mathrm{~cm}^{2}\right)$ was obtained from those grown in sand (Figure 7). Leaf area of Swiss chard grown in sand, gravel and sawdust peaked at 2 WAT and then decreased with age until the experiment was terminated. Swiss chard grown in mixture of sand and vermiculite (1:1) showed an increase in leaf area from 2 to 3 WAT.

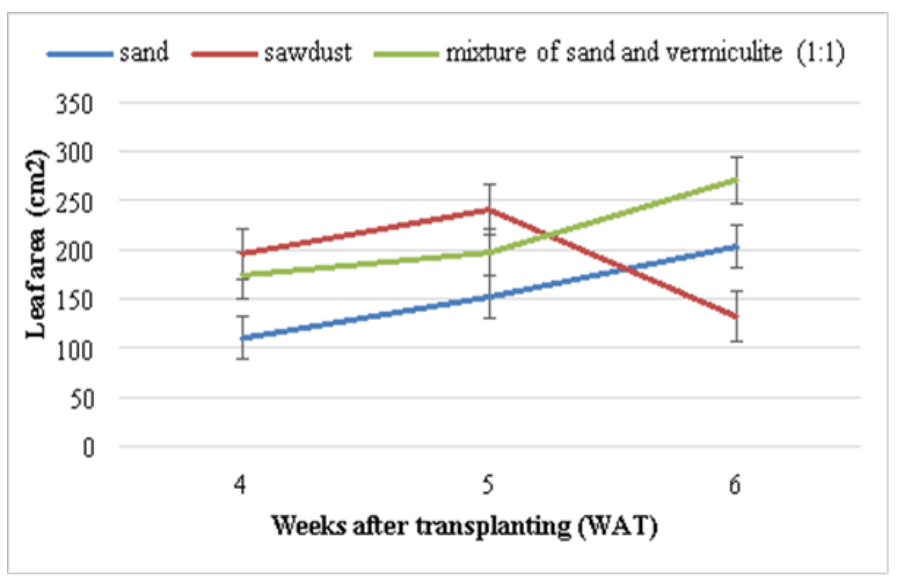

Figure 7 Effect of different media on the leaf area of Swiss chard.Vertical bars are standard error (SE) below and above the mean.

\section{Discussion}

The use of alternative soilless media for the production of vegetables requires knowledge of their physical and chemical characteristics to result in the best conditions for plant growth. ${ }^{13}$ All plants require more or less the same minerals to complete their life cycles, yet, an optimum and balanced level of nutrients is necessary for optimum growth and higher production of quality vegetable production. ${ }^{14}$ Swiss chard grown in mixture of vermiculite and sand (1:1) had the highest plant height than the other plants grown in the other media. According to Handreck and Black, ${ }^{14}$ a good potting mixture should have a good drainage, good aeration and good water and nutrient holding capacity.
The lowest plant height recorded was from Swiss chard plant grown in sand. Hartman et al..$^{15}$ stated that sand consists of small rock particles, $0.05-2.0 \mathrm{~mm}$ in diameter. Therefore, it is has a poor water and nutrient holding capacity. Johnson et al. ${ }^{16}$ reported that vegetative growth of green pepper plants in sand had better plant height with several shoots which resulted in higher number of fruits harvested. Similar results were obtained by Lee et al. ${ }^{17}$ in tomatoes where plants grown in sand produced higher yields.

The highest number of leaves recorded was Swiss chard plants grown using the mixture of vermiculite and sand (1:1). Vermiculite has the capability to hold water and nutrients and they tend not to dry out fast. A mixture that contains sand, roots are able to penetrate and have access to the water held in them. ${ }^{18}$

Swiss chard plants with the highest leaf area were recorded in the mixture of sand and vermiculite (1:1). The mixture consists of properties of sand which have a good drainage and aeration, while vermiculite on the other hand has the ability to hold nutrients and water. The longest root recorded was obtained from the mixture of sand and vermiculite (1:1). According to Handreck and Black, ${ }^{14}$ roots are able to penetrate and have access to the water held in them.

Sawdust and sand particles have a high porosity. ${ }^{19}$ The highest fresh mass was obtained in plants grown in the mixture of sand and vermiculite (1:1). Also the mixture of the two media may have complimented each other thus providing suitable conditions for plant growth. Overall, the Swiss chard planted in the mixture of sand and vermiculite had the highest fresh leaf mass, fresh root mass, dry leaf mass and dry root mass. There were significant differences in leaf dry mass of Swiss chard grown in different media. The highest leaf dry mass was obtained from plants grown in mixture of sand and vermiculite $(1: 1)$ and the lowest in sand. Dwayne ${ }^{20}$ reported that vermiculite has a good cation-exchange capacity and is slightly alkaline, thus it performed much better than the other media.

The highest leaf area was obtained in sawdust and mixture of sand and vermiculite (1:1) respectively. VanAverbeke et al. ${ }^{21}$ reported that the physical properties of these substrates have large particles sizes (0.2-2.0 $\mathrm{mm}$ in diameter) and presents a higher percentage pore space suitable for the growth and development of the root system hence higher yield. 22,23

\section{Conclusion}

Swiss chard grown in sawdust gave the best results in all the parameters determined which is of good advantage since only the leaves are eaten. Swiss chard grown in sand gave the worst results almost in all parameters determined. The mixture sand and vermiculite (1:1) proved also to be a good medium since it was always the second best in all the parameters determined. Other media and different hydroponics systems can be used to compare the growth of horticultural crops such as Swiss chard for food security throughout the country.

\section{Acknowledgments}

None.

\section{Conflicts of interest}

Authors declare that there is no conflict of interest. 


\section{References}

1. Conte A, Conversa G., Scrocco C. Post-Harvest and Technology. Journal of Horticulture. 2008;50(2):190-196.

2. http://www.africanews.com/site/list_messages/12337.HYPERLINK "http://www.africanews.com/site/list messages/12337.\%2002/10/2017" $02 / 10 / 2017$

3. Rico D, Martin, Diana A. Extending and measuring the quality of fresh cut fruit and vegetables. A Review. Trends in Food Technology. Journal of Food Science. 2007;18:373-386.

4. Bergquest S. Bioactive compounds in baby swiss chard (Spinacia oleracea L.) effects of pre- and postharvest factors. Journal of Science of Food and Agriculture. 2006;86:346-355.

5. Schroeder CS, Seagle ED, Felton LM, et al. Introduction to horticulture third edition. Interstate Publisher Inc., London, United Kingdom; 2000.

6. Soundy P, Cantliffe DJ, Hochmuth GJ, et al. Nutrient requirements for lettuce transplants using a floatation irrigation system. I. Phosphorus. Journal of Horticulture Science. 2001;36:1066-1070.

7. Grunert O, Perneel M, Vandaele S. Peat-based organic grow-bags as a solution to the mineral wool waste problem// Mires and Peat. Journal of Science of Horticulture. 2008;3:1-5.

8. Murdock G. Soils and land capability in swaziland. Swaziland Ministry of Agriculture, Mbabane. Swaziland. 1970.

9. Eckert D, Sims JT. Recommended Soil $\mathrm{pH}$ and lime requirement tests In: JT Sims, A Wolf, editors. recommended soil testing procedures for the northeastern united states. Northeast regional bulletin \#493. 3rd ed. Agricultural Experiment Station, Newark, DE; 19-25:2011.

10. Yeshitila M. Taye, M. Non-destructivr prediction models for estimation of leaf area for most commnonly grown vegetable crops in Ethiopia. Science Journal of Applied Mathematics and Statistics. 2016;4(5):202-216.

11. Nissen O. Mstat C. A microcomputer program for the design, management and analysis of agronomic research experiments. Michigan State University, East Lansing Michigan, USA; 1989.
12. Gomez KA, Gomez AA. Statistical procedures for agricultural research. 2nd ed. John Wiley and sons. Singapore; 1984.

13. Wahome PK, Oseni TO, Masarirambi MT, et al. Effects of different hydroponics systems and growing media on the vegetative yield and cut flower quality of gypsophila (Gysophila panaculata L.). World Journal of Agricultural Sciences. 2011;7(6):692-698.

14. Handreck K, Black N. Growing media for ornamental plants and turf. University of new south water press ltd, Sydney, Australia; 2010.

15. Hartman HT, Kester DE, Davies FT. Plant propagation-principles and practices 5th ed. Prentice Hall. Englewood Cliffs, New Jersey, USA; 1990

16. Johnson H, Marsh WA, Hall AE, et al. Greenhouse tomato production. Division of agricultural science. USA; 1975.

17. Lee B, Cho J, Park S, et al. Effects of substrates on the growth and fruit quality of hydroponically grown tomato (Lycopersicon esculentum Mill cv Kantika). Acta Horticulture. 1999;483:147-154.

18. Sundell AF. Practical gardening \& food production in pictures Properties of growing media. New Orleans, Louisiana, USA; 2008

19. De Broodt M, Verdonck O. The physical properties of the substrates in horticulture. Acta Horticulture. 1972;26:37-44.

20. Dewayne LI. Growth media of container grown ornamental plants. The Environmental Horticulture Department, Florida, USA; 2003.

21. VanAverbeke A, Yoganathan S. Using kraal manure as fertilizer Department of Agriculture, South Africa; 2003.

22. Albery WJ, Haggett BGD, Svanberg LR. The development of sensors for hydroponics. Spinger-Verlag, New York, USA; 1985.

23. Gruda N, Schnitzler WH. Suitability of wood fiber substrates for production of vegetable transplants. The effect of wood fiber substrates and their volume weights on the growth of tomato transplants. Journal of Scientia Horticulturae. 2004;100:333-340. 